\title{
Faktor-faktor yang Mempengaruhi Mahasiswa Baru Memilih Program Studi padaFakultas Ekonomi Universitas Samudra
}

\author{
Syardiansah \\ Fakultas Ekonomi, Universitas Samudra \\ e-mail: syar_di_ansah@yahoo.com
}

\begin{abstract}
Abstrak
Penelitian ini dilakukan untuk mengetahui faktor-faktor dominan apa saja yang mempengaruhi mahasiswa baru memilih program studi pada Fakultas Ekonomi Universitas Samudra. Faktor-faktor yang diindikasikan memiliki pengaruh terdiri dari 4 faktor yang terdiri dari faktor kebudayaan, sosial, pribadi dan psikologi. Dari ke 4 faktor-faktor tersebut dijabarkan kedalam 12 faktor yang telah lulus uji validitas dan reabilitas yang terdiri dari faktor kebudayaan karena adanya muatan lokal, faktor kebudayaan karena pengaruh dari lingkungan tempat tinggal, faktor kebudayaan karena persamaan segi budaya dan lingkungan, faktor kebudayaan karena dapat bermanfaat bagi pengembangan budaya dan lingkungan, faktor sosial karena komunitas lingkungan sepermainan dan teman sekolah, faktor sosial karena pendapat anggota keluarga dan faktor sosial karena status keluarga dalam masyarakat, factor pribadi karena pendapatan orang tua, faktor pribadi karena melihat keberhasilan lulusannya, faktor psikologi karena meningkatkan status sosial, faktor psikologis karena mudahnya penyelesaian studi, dan faktor psikologis karena tenaga pengajar (Dosen) yang berkualitas. Dari hasil pengolahan data dan pembahasan diperoleh bahwa ke dua belas faktor yang dianggap menjadi faktor-faktor mahasiswa baru memilih program studi pada Fakultas Ekonomi Universitas Samudra terdapat 5 faktor dominan yang sangat mempengaruhi yaitu faktor budaya karena adanya muatan lokal, pengaruh lingkungan tempat tinggal, persamaan segi budaya dan lingkungan, pengembangan budaya dan lingkungan dan faktor sosial karena komunitas lingkungan sepermanian dan teman sekolah.
\end{abstract}

Kata Kunci: Faktor Kebudayaan, Sosial, Pribadi, Psikologis

\section{PENDAHULUAN}

Dunia pendidikan dewasa ini semakin dituntun untuk meningkatkan hasil lulusan yang memiliki kompetensi yang unggul dan dapat berdaya guna dalam dunia pekerjaan. Hal tersebut mengindikasikan persaingan yang semakin ketat. Untuk dapat berperan dan bersaing dalam kondisi dunia yang semakin maju dan bebas, pendidikan menjadi syarat mutlak. Pendidikan menjadi sarana untuk mengembangkan pengetahuan dan kemampuan melalui pengajaran yang diberikan. Namun disisi lain pendidikan yang tidak didukung oleh penyediaan fasilitas yang baik tidak akan mampu untuk menghasilkan output yang diinginkan. Ini merupakan salah satu faktor mengapa mahasiswa-mahasiswa baru untuk memilih tempat pendidikan agar dapat mencapai cita-citanya.

Lembaga perguruan tinggi merupakan salah satu tujuan masyarakat dalam meningkatkan pendidikan yang fokus pada satu bidang konsentrasi yang dibutuhkan untuk memasuki dunia kerja. Mendapatkan pekerjaan yang layak merupakan salah satu tujuan belajar di Perguruan Tinggi.Kuliah di universitas ataupun perguruan tinggi bukan lagi dengan tujuan utama mencari ilmu, tapi ada motif lain yaitu kelak setelah lulus berharap mendapatkan pekerjaan layak. Pekerjaan dapat menjadi tolok ukur 
keberhasilan seseorang dari hasil belajar di Perguruan Tinggi. Seperti yang telah disebutkan dalam undang-undang nomor 20 pasal 1 tahun 2003 tentang Sistem Pendidikan Nasional, bahwa pendidikan adalah usaha sadar dan terencana untuk mewujudkan suasana belajar dan proses pembelajaran agar peserta didik secara aktif mengembangkan potensi dirinya untuk memiliki kekuatan spiritual keagamaan, pengendalian diri, kepribadian, kecerdasan, akhlak mulia, serta keterampilan yang diperlukan dirinya, masyarakat, Bangsa dan Negara. Dari Undang-Undang no 20 pasal 1 tahun 2003 tersebut perlu diketahui pula faktor-faktor apa saja yang dapat menjadi pendukung suasana dan proses belajar agar peserta didik dapat aktif mengembangkan potensi dirinya. Ini tidak boleh lepas dari pengaruh lingkungan dan minat mahasiswa itu sendiri untuk dapat mencapai cita-citanya. Dimana ini semua kembali kepada institusi penyelengaran pendidikan tersebut, sanggup atau tidak dalam memenuhi segala tuntutan yang diinginkan untuk dapat memajukan pendidikan terutama meningkatkan minat dari peserta didik untuk memilih institusi tersebut sebagai lembaga pendidikan agar cita-cita yang diinginkan oleh peserta didik dapat tercapai.

Hakikat Perguruan Tinggi yaitu sebagai proses belajar mengajar adalah berusaha mencari informasi dan pengetahuan serta mengajar. Perguruan tinggi sebagai proses belajar mengajar yang berarti berusaha memperoleh pengetahuan dan prilaku yang benar tentang sesuatu dari lingkungannya. Sedangkan mengajar adalah mengkomunikasikan pengetahuan dan perilaku tadi kepada oranglain sedemikian rupa sehingga orang lain mampu mengembangkan lebih lanjut. Selanjutnya Perguruan Tinggi merupakan pendekatan Mikro dan Makro, pendekatan mikro yaitu tinjauan terhadap proses belajar mengajar yang terjadi didalam lembaga, sedangkan pendekatan makro tinjauan terhadap proses belajarmengajar yang berlangsung antara lembaga dengan lingkungannya. Sedangkan perguruan Tinggi sebagai komunitas ilimiah, yakni Perguruan Tinggi adalah komunitas ilmiah atau komunitas pelajar. Jadi perguruan tinggi sebagai komunitasdapat berfungsi menstransformasi dan melestarikan sistem nilai, tata cara danpengetahuan. Perguruan tinggi juga didukung dan diberi tugas menyelenggarakan program tetap yang disebut kurikulum.

Fakultas Ekonomi Universitas Samudra semenjak berdirinya hingga saat ini telah memiliki tiga program studi yaitu Manajemen, Ekonomi Pembangunan dan Akuntansi. Dari ketiga jurusan tersebut telah banyak menghasilkan lulusan yang diterima untuk bekerja baik di lembaga pemerintah maupun swasta. Pada saat ini masing-masing program studi yang ada di Fakultas Ekonomi terus meningkatkan kualitas mutu pendidikan dengan bisa dilihat dari Akreditasi masingmasing program studi tersebut. Inilah yang bisa menjadi salah satu nilai jual agar para peserta didik atau mahasiswa baru mau memilih program studi yang diminatinya untuk menuntut ilmu dan meraih cita-citanya.

Setiap lembaga pendidikan khususnya program studi yang ada dibawah naungan fakultas memiliki peminat masing-masing, mereka memiliki pertimbangan-pertimbangan tertentu dalam memilih program studi. Demikian pula halnya dengan mahasiswa yang memilih program studi di fakultas ekonomi, mereka memiliki pertimbangan yang berbeda-beda. Hal ini dikarenakan mereka memiliki minat, bakat, persepsi, citacita dan pandangan yang berbeda dalam minilai suatu program studi.Untuk dapat mengetahui pertimbangan-pertimbangan apa saja yang dijadikan dasar oleh mahasiswa dalam memilih program studi di fakultas ekonomi peneliti bertujuan untuk mengetahui faktor-faktor apa saja yang mempengaruhi minat mahasiswa dalam memilih program studi di Fakultas Ekonomi Universitas Samudra.

\section{Perguruan Tinggi}

Peranan perguruan tinggi dalam menciptakan sumber daya manusia berkualitas dipandang potensial dan sangat menetukan. Masalah yang perludicermati adalah sudah sejauh mana perguruan tinggi mampu menghasilkan lulusan yang berkualitas, mandiri, dan professional pada 
bidang yang ditekuni. Membincangkan lulusan yang mandiri dan professional adalah menjadi tanggungjawab perguruan tinggi dalam hal bagaimana mengolah dan memanfaatkan program dan kegiatan ektrakurikuler atau kegiatan kemahasiswaan secara optimal. Antara lain adalah mengolah dan memanfaatkan tenaga pembimbing kemahasiswaan, waktu, di luar kegiatan akademik, menyusun program dan kegiatan yang berkualitas, menyusun pembiayaan yang memadai dan sarana prasarana. Apabila hal tersebut di atas dikelola secara professional akan mampu menciptakan sumber daya manusia berkualitas dan dengan sendirinya akan meluluskan lulusan yang mandiri dan professional. Keberhasilan suatu perguruan tinggi dapat diukur atau lebih ditentukan oleh kemampuan menciptakan mahasiswa sebagai pencari kerja (Fadjar, 2005).

Perguruan tinggi untuk dapat menarik minat para mahasiswa baru tentu saja harus meningkatkan pelayanannya. Menurut Fitzsimmons dalam (Berry dan Parasuraman 2001), pelayanan dapat dikatakan dengan bermutu, sebaliknya jika kenyataan kurang dari yang diharapkan, pelayanan dapat dikatakan dengan tidak bermutu. Namunapabila kenyataannya sama dengan yang diharapkan, maka kualitas pelayanan disebut memuaskan.

Parasuraman (2005) menjelaskan bahwa terdapat lima dimensikualitas pelayanan, dimana jasa pendidikan merupakan bentuk jasa yangmelibatkan tingkat interaksi yang tinggi antara penyedia jasa pendidikan (lembagapendidikan) dan pengguna jasa pendidikan, dimensi jasa pendidikan jasa tersebutdapat dijelaskan sebagai berikut:

1. Tangible (bukti fisik)

Yaitu meliputi fasilitas fisik, perlengkapan, karyawan/staf pengajar dan sarana komunikasi. Misalnya fasilitas pembelajaran (gedung), fasilitas laboratorium, fasilitas perpustakaan, media pembelajaran, kantin, tempat parkir, sarana ibadah, fasilitas olahraga, serta busana penampilan staf administrasi maupun staf pengajar.

2. Reability (keandalan)

Yakni kemampuan memberikan pelayanan yang dijanjikan dengan segera atau cepat, akurat dan memuaskan. Misalnya mata pelajaran yang benar-benar sesuai dengan kebutuhan, jadwal pembelajaran, proses pembelajaran yang akurat, penilaian yang objektif, bimbingan dan penyuluhan, serta aktivitaslain yang semuanya untuk memperlancar proses pembelajaran peserta didik.

3. Ressponsiveness (daya tanggap)

Yaitu mencakup pengetahuan, kompetensi, kesopanan, respek terhadap peserta didik, serta memiliki sifat dapat dipercaya, bebas dari bahaya dan keraguraguan. Misalnya seluruh staf administrasi, staf pengajar maupun pejabat struktural harus benar-benar kompeten di bidangnya sehingga reputasi bidang lembaga pendidikan positif dimata masyarakat.

4. Empathy (empati)

Yaitu kemudahan dalam melakukan hubungan, komunikasi dengan baik, perhatian pribadi dan memahami kebutuhan peserta didiknya. Misalnya staf pengajar mengenal siswanya yang mengikuti proses pembelajaran, guru bias benar-benar berperan sesuai dengan fungsinya, perhatian yang tulus diberikan kepada para siswanya berupa kemudahan mendapatkan pelayanan, keramahan, komunikasi serta kemampuan memahami kebutuhan siswanya.

Menurut Maxwel dalam

(Parasuraman, 2005), ada enam dimensi kualitas jasa pendidikan, yaitu:

1. Akses yang berhubungan dengan kemudahan mendapatkan jasa pendidikan yang diperoleh di tempat yang mudah dijangkau pada waktu yang tepat dannyaman.

2. Kecocokan dengan tingkat kebutuhan pelanggan, yaitu kecocokan akan profil tingkat pendidikan populasi dan kelompok yang membutuhkannya.

3. Efektivitas yang berhubungan dengan adanya kemampuan penyaji jasa pendidikan (staf pengajar) untuk melayani yang menciptakan hasil yangdiinginkan.

4. Ekuitas yang berhubungan dengan distribusi sumber-sumber pelayanan 
lembaga pendidikan yang adil dalam suatu sistem yang didukung secaraumum.

5. Diterima secara sosial yang berhubungan dengan kondisi lingkungan, komunikasi dan kebebasan, atau keleluasaan pribadi.

6. Efisiensi dan ekonomis yang mengacu kepada pengertian layanan terbaikuntuk besarnya biaya yang tepat.

Menurut Berry dan Parasuraman (2001), bahwa salah satu konsepyang memiliki kaitan erat dan memiliki dampak langsung terhadap keberhasilankualitas jasa adalah sistem informasi ada lima petunjuk yang perlu dilakukandalam mengembangkan kualitas jasa pendidikan yang efektif melalui sisteminformasi, yaitu sebagai berikut:

1. Mengukur besarnya harapan penggunaan jasa pendidikan (siswa/mahasiswa)atas pelayanan yang diberikan lembaga pendidikan. Lembaga pendidikanharus dapat mengukur besarnya harapan yang muncul atas pelayanan yangdiberikan kepada pelanggan. Misalnya berapa besar tingkat kepuasansiswa/mahasiswa atas pelayanan administrasi, pelayanan staf pengajar ataupemimpin lembaga pendidikan, pelayanan atas kesediaan fasilitaspembelajaran dan sebagainya.

2. Menentukan dimana titik berat kualitas informasi. Lembaga pendidikan harusmenetapkan titik berat kualitas informasi yang ingin dicapai. Misalnya, titikberat kualitas informasi pada proses keputusan pemimpin lembaga pendidikanyang berkaitan dengan peningkatan pelayanan yang diharapkan pelanggan.

3. Mengetahui saran pelanggan. Lembaga pendidikan dituntut untukmendengarkan dan memahami saran pelanggan (siswa/mahasiswa) mengenaijasa pendidikan yang diberikan. Misalnya, mengenai fasilitas pembelajaran,keunggulan staf pengajar dan sarana perpustakaan.

4. Menghubungkan kinerja pelayanan dan output yang dihasilkan oleh lembagapendidikan. Lembaga pendidikan diharapkan mampu mengaitkan kinerjapelayanan dengan tujuan lembaga pendidikan. Apakah akumulasi kinerjapelayanan dapat berakhir pada loyalitas siswa/mahasiswa dan peningkatanpangsa pasar.

5. Menjangkau seluruh staf (pegawai). Penerapan system informasi dalamkualitas jasa harus mampu mencakup keseluruhan individu yang terkait dalam hierarki lembaga pendidikan. Sistem tersebut harus dirancang sedemikian rupa agar semua staf yang berada pada fungsi masing-masing mendapatkaninformasi sesuai dengan porsinya

\section{Perilaku Konsumen}

Menurut dan Amstrong (2012), perilaku membeli konsumen (consumer buying behaviour) merujuk pada perilaku membeli konsumen akhir-individu dan rumah tangga yang membeli barang dan jasa untuk konsumsi pribadi. Dari pengertian tersebut perilaku membeli konsumen terfokus pada konsumen akhir yang membeli produk barang maupun jasa untuk konsumsi pribadi. Menurut Kotler dan Amstrong, (2012), perilaku konsumen dipengaruhi oleh faktor budaya, sosial, pribadi, dan psikologis.

Sedangkan menurut Solomon dan Stuart (2003), Consumer behaviour is the process individuals or groups go through to select, purchase, or use goods, ideas, or experiences to satisfy their needs dan desires. Pengertian tersebut mengindikasikan agar pemasar mencoba untuk mengenal bahwa pembuatan keputusan oleh konsumen merupakan sebuah proses yang berkelanjutan.

Mowen dan Minor (2002) menyatakan bahwa perilaku konsumen sebagai suatu studi tentang unit pembelian (buying units) dan proses pertukaran yang melibatkan perolehan, konsumsi dan pembuangan barang, jasa, pengalaman, serta ide-ide. Sedangkan berdasarkan Louden dan Bitta (dalam Umar, 2003), Perilaku konsumen dengan suatu proses pengambilan keputusan dan aktivitas individu secara fisik yang dilibatkan dalam mengevaluasi, memperoleh, menggunakan atau dapat mempergunakan barang-barang dan jasa.

Adapun faktor-faktor utama yang mempengaruhi perilaku konsumen adalah:

1. Faktor Kebudayaan 
Faktor budaya merupakan pengaruh yang paling luas dan paling dalam. Studi mengenai budaya adalah studi mengebai semua aspek masyarakat yaitubahasa, pengetahuan, hukum dan adat yang memberikan karakter dan kepribadian khusus bagi masyarakat yang bersangkutan. Kebudayaan merupakan faktor penentu yang paling dasar dari keinginandan perilaku seseorang. Bila makhluk-makhluk lainnya bertindak berdasarkannaluri, maka perilaku manusia umumnya dipelajari (Setiadi, 2003).

Dalam kontek perilaku konsumen budaya didefenisikan sebagaikeyakinan, nilai dan adat adat yang digunakan untuk mengatur perilakumasyarakat tertentu sebagai konsumen. Keyakinan dan nilai merupakan panduan bagi perilaku konsumen, sedangkan adat merupakan cara berperilaku yang umumdan dapat diterima.Agar dapat menyediakan kebutuhan-kebutuhan akan peningkatan keilmuan dan pengalaman baru yang diinginkan mahasiswa faktor budaya mempunyai pengaruh yang paling luas dan paling dalam terhadap keputusan mahasiswa. Pemasar harus memahami yang dimainkan oleh kebudayaan (kultur), budaya (sub kultur) dan kelas sosial konsumen (Simamora, 2004).

Tiap kebudayaan (kultur) mempunyai budaya (sub kultur) yang lebihkecil, atau kelompok orang dengan sistem nilai sama berdasarkan pengalaman dansituasi yang sama. Seperti kelompok kebangsaan yang bertempat tinggal pada suatu daerah mempunyai citra rasa dan minat etnik yang khas. Demikian pula dengan halnya dengan kelompok keagamaan. Daerah geografik adalah merupakan budaya (sub kultur), ini merupakan segmen pasar yang paling penting dan pemasar sering menemukan manfaat dengan merancang produk yang disesuaikandengan budaya (sub kultur) tersebut (Simamora, 2007)

Kelas sosial yaitu pembagian anggota masyarakat menjadi sebuah hierarki dan kelas-kelas status berbeda, sehingga anggota dari suatu kelas memiliki status relatif sama dan bila dibandingkan dengan anggota kelas lain akan memiliki statusyang lebih tinggi atau rendah (Kotler, 2004)

2. Faktor Sosial

Perilaku seorang konsumen dipengaruhi oleh faktor-faktor sosial seperti kelompok acuan, keluarga, peran dan status.Secara tradisional keluarga diartikan sebagai dua orang atau lebih yang dikaitkan dengan hubungan darah, perkawinan atau adopsi yang tinggal bersama-sama (Schiffman, 2004). Keluarga mempunyai pengaruh yang paling besar terhadap tingkah laku pembelian konsumen dan merupakan target utama bagi pemasaran berbagai produk barang dan jasa. Secara tradisional keluarga didefenisikan sebagai dua atau lebih orang yang dihubungkan dengan pertalian darah, perkawinan atau adopsi yang memiliki tempat tinggal bersama, dan secara dinamis individu yang membentuk sebuah keluarga dapat digambarkan sebagai anggota dari anggota masyarakat yang paling dasar yang tinggal bersama dan berinteraksi untuk memenuhi kebutuhan individu maupun antar individu mereka.

Kelompok merupakan dua individu atau lebih yang berinteraksi dan saling bergantung untuk dapat mencapai tujuan tertentu (Robbins, 2003). Kelompok referensi seseorang terdiri dari seluruh kelompok yang mempunyai pengaruh langsung terhadap sikap atau prilaku seseorang. Perilaku konsumen banyak dipengaruhi oleh kelompok-kelompok kecil, diantaranya adalah kelompokkelompok primer bahwa dengan adanya interaksi yang cukup berkesinambungan seperti keluarga, teman, tetangga serta teman sejawat.

Status merupakan posisi atau peringkat yang ditentukan secara sosial yang diberikan kepada kelompok lain (Robbins,2003). Setiap peran membawa status yang menggambarkan penghargaan umum terhadap peran tersebut oleh masyarakat. Orang terkadang memilih produk yang menunjukkan status mereka di masyarakat. 
3. Faktor Pribadi

Keputusan membeli juga dipengaruhi oleh karakteristik pribadi.Karakteristik tersebut meliputi usia dan tahap siklus hidup, pekerjaan, keadaanekonomi, gaya hidup, serta kepribadian dan konsep diri pembeli. Orang membeli barang dan jasa yang berbeda-beda sepanjang hidupnya. Mereka membeli makanan bayi pada tahun-tahun awal kehidupannya. Selera orang terhadap pakaian, perabot, rekreasi serta pendidikan juga berhubungandengan usia. Konsumsi juga dibentuk oleh siklus hidup keluarga. Pemasar sering memilih kelompok- kelompok berdasarkan siklus hidup sebagai pasar sasarannya.

Pekerjaan seseorang mempengaruhi pola konsumsinya. Misalnya, pekerja akan membeli perlengkapan kerja sesuai denagn kemampuan ekonomi mereka. Begitu juga dengan direktur perusahaan akan membeli barang-barang yang mahal,transportasi dengan menggunakan pesawat udara dan lain-lain. Dengan melihat adanya perbedaan tersebut maka perusahaan dapat mengkhususkan produknya untuk kelompok profesi tertentu.

Orang yang berasal dari sub budaya, kelas ekonomi dan pekerjaan yang sama mungkin dapat menjalankan gaya hidup yang berbeda. Gaya hidup adalah pola hidup seseorang yang diekspresikan dalam aktivitas, minat dan opininya. Gaya hidup menggambarkan keseluruhan dari seseorang yang berinteraksi dengan lingkungannya. Para pemasar berusaha mencari hubungan antara produk yang mereka hasilkan dengan kelompok gaya hidup.

Kepribadian sebagai karakteristik psikologis seseorang yangb berbeda dengan orang lain, yang menyebabkan tanggapan yang relatief konsisten dan bertahan lama terhadap lingkungannya. Kepribadian biasanya dijelaskan dengan ciri-ciri bawaan seperti kepercayaan diri, dominasi, otonomi, perbedaan, kondisi sosial, keadaan pembelaan diri dan kemampuan yang beradaptasi. Kepribadian dapat menjadi variable yang sangat berguna dalam mmenganalisa perilaku konsumen dengan syarat jenis kepribadian tersebut dapat diklasifikasikan dengan akurat asalkan terdapat korelasi yang kuat antara jenis kepribadian tertentu dengan pilihan produk dan merek. Faktor lain yang dapat menentukan tingkah lakupembeli adalah konsep diri. Konsep diri adalah cara bagi seseorang untuk melihat dirinya sendiri dan pada saat yang sama ia mempunyai gambaran tentang diri orang lain.

4. Faktor Psikologis

Ada empat faktor psikologis utama yang dapat mempengaruhi pilihan pembeli seseorang, yaitu motivasi, persepsi, pembelajaran serta keyakinan dan sikap pembeli itu sendiri. Motivasi adalah kekuatan yang mendorong dari dalam diri manusia yang membuat dirinya melakukan sesuatu. Dorongan tersebut disebabkan oleh suatu kebutuhan yang belum terpenuhi.

Pengertian persepsi dari Kamus Psikologi adalah berasal dari BahasaInggris perception yang artinya: persepsi, penglihatan, tanggapan; yaitu proses seseorang menjadi sadar akan segala sesuatu dalam lingkungannya melalui indera-indera yang dimilikinya atau pengetahuan lingkungan yang diperoleh melalui interpretasi data indera (Kartono \& Gulo, 1987).

Keyakinan (believe) merupakan gambaran pemikiran yang dianut olehseseorang mengenai suatu hal. Keyakinan mempengaruhi kepercayaan. Salah satu elemen yang sangat menonjol adalah perasaan emosional baik yang positifmaupun yang negative terhadap sebuah barang atau jasa.Sikap (attitude) adalah merupakan faktor penentu perilaku, karena sikap itu berhubungan dengan persepsi, kepribadian, belajar dan motivasi.

\section{Hipotesis}

Berdasarkan uraian latar belakang dan dikaitkan dengan telaah teoritis dan empiris terdahulu, hipotesisnya yaitu: Faktor-faktor yang mempengaruhi mahasiswa baru memilih 
program studi pada Fakultas Ekonomi Universitas Samudra terdiri dari kebudayaan, status sosial, pribadi dan psikologis.

\section{METODE PENELITIAN}

Penelitian ini menggunakan metode survey dengan angket berupa kuesioner yang dibagikan kepada mahasiswa baru angkatan 2017/2018 yang menjadi respondennya. Kuesioner menggunakan skala Likert.

Populasi dalam penelitian ini berjumlah 240 orang yang terdiri dari program studi Manajemen, Ekonomi Pembangunan dan Akuntansi tingkat 1 tahun akademik 2017/2018. Pengambilan sampel dilakukan secara acak kepada mahasiswa dengan menggunakan rumus Slovin:

Dimana:

$$
n=\frac{N}{1+N \cdot e^{2}}
$$

$$
\begin{aligned}
& \mathrm{n}=\text { ukuran sampel } \\
& \mathrm{N}=\text { ukuran populasi } \\
& \mathrm{e}=\text { persen kelonggaran } \\
& \begin{array}{c}
\text { karena ketidaktelitian } \\
\text { sampel }
\end{array}
\end{aligned}
$$

maka jumlah sampel pada penilitian ini adalah:

$$
\begin{aligned}
n & =\frac{240}{1+240 \cdot(10 \%)^{2}} \\
& =70,58 \approx 71 \text { (dibulatkan) }
\end{aligned}
$$

Jadi, sampel penelitian yangdigunakan untuk mewakili populasi penelitian berjumlah 71 orang.

\section{HASIL ANALISIS}

Hasil analisis statistik mengenai faktorfaktor yang mempengaruhi mahasiswa baru memilih program studi pada Fakultas Ekonomi Universitas Samudra diperoleh sebagai berikut:

Tabel 1. Case Processing Summary

\begin{tabular}{llrr}
\hline & \multicolumn{1}{c}{$\mathrm{N}$} & \multicolumn{2}{c}{$\%$} \\
\hline \multirow{3}{*}{ Cases } & Valid & 71 & 100.0 \\
\cline { 2 - 4 } & Excluded $^{\mathrm{a}}$ & 0 & .0 \\
\cline { 2 - 4 } & Total & 71 & 100.0 \\
\hline
\end{tabular}

a. Listwise deletion based on all variables in the procedure.

Sumber: Hasil Penelitian (2017)
Tabel 2. Reliability Statistics

\begin{tabular}{lr}
\hline \multicolumn{3}{c}{ Cronbach's Alpha } \\
\hline \multicolumn{4}{c}{ N of Items } \\
\hline Sumber: Hasil Penelitian (2017) \\
Uji reliabilitas digunakan untuk \\
mengetahui tingkat keandalan item-item \\
pernyataan dalam kuesioner, dengan metode \\
Cronbach's Alpha. Berdasarkan hasil analisis \\
pada tabel 1 dapat dilihat bahwa nilai \\
Cronbach's Alpha sebesar 0,641. Dengan \\
membandingkan kategori nilai alpha yang \\
digunakan dalam penelitian ini (Sekaran, \\
2000) sebagai berikut:
\end{tabular}

1. Nilai alpha antara 0,8 sampai dengan 1 dikategorikan reliabilitas baik

2. Nilai alpha antara 0,6 sampai dengan 0,79 dikategorikan reliabilitas diterima

3. Nilai alpha kurang dari 0,6 dikategorikan reliabilitas kurang baik

Maka dapat diambil kesimpulan bahwa itemitem pernyataan dalam kuesioner memiliki keandalan yang diterima.

\section{Pembahasan}

Pengolahan data atas faktor-faktor yang mempengaruhi mahasiswa baru memilih program studi pada Fakultas Ekonomi Universitas Samudra dilakukan dengan teknik

\begin{tabular}{|c|c|c|}
\hline \multirow{3}{*}{$\begin{array}{l}\text { Bartlett's Test of } \\
\text { Sphericity }\end{array}$} & $\begin{array}{l}\text { Approx. Chi- } \\
\text { Square }\end{array}$ & 180.046 \\
\hline & Df & 66 \\
\hline & Sig. & .000 \\
\hline
\end{tabular}
analisis faktor yang menggunakan software SPSS. Berikut ditujukkan nilai angka KMO Measure Of Sampling Adequancy (MSA)

\section{Tabel 3. KMO and Bartlett's Test}

Kaiser-Meyer-Olkin Measure of

Sampling Adequacy.

Sumber: Hasil Penelitian (2017)

Terlihat angka K-M-O Measure Of Sampling Adequancy (MSA) adalah 0,629 sedangkan angka MSA harus diatas 0,5 maka kumpulan Variabel tersebut dapat diproses lebih lanjut, selanjutnya tiap variabel dianalisis untuk mengetahui mana yang akan diproses lebih lanjut dan mana yang harus dikeluarkan. 
Tabel 4. Anti-image Matrices

\begin{tabular}{|c|c|c|c|c|c|c|c|c|c|c|c|c|c|}
\hline & & $\mathrm{V} 1$ & $\mathrm{~V} 2$ & V3 & V5 & V6 & V7 & V9 & $\mathrm{V} 13$ & V14 & V18 & V19 & V20 \\
\hline & $\mathrm{V} 1$ & $.596^{\mathrm{a}}$ & -.044 & -.134 & .248 & -.292 & -.044 & .193 & .023 & -.289 & .076 & -.234 & -.317 \\
\hline & V2 & -.044 & $.603^{\mathrm{a}}$ & -.164 & .066 & -.126 & -.050 & .032 & .147 & -.085 & .119 & -.040 & -.240 \\
\hline & V3 & -.134 & -.164 & $.758^{\mathrm{a}}$ & -.128 & -.091 & -.202 & .050 & -.157 & .069 & .056 & -.079 & .110 \\
\hline & V5 & .248 & .066 & -.128 & $.516^{\mathrm{a}}$ & .011 & -.247 & .051 & .073 & -.207 & -.322 & .013 & -.121 \\
\hline & V6 & -.292 & -.126 & -.091 & .011 & $.504^{\mathrm{a}}$ & -.183 & -.277 & -.095 & .068 & -.295 & .174 & .334 \\
\hline Anti-image & V7 & -.044 & -.050 & -.202 & -.247 & -.183 & $.655^{a}$ & -.211 & -.328 & .063 & .242 & .128 & -.163 \\
\hline \multirow[t]{6}{*}{ Correlation } & V9 & .193 & .032 & .050 & .051 & -.277 & -.211 & $.653^{\mathrm{a}}$ & .065 & -.133 & .033 & -.441 & -.136 \\
\hline & $\mathrm{V} 13$ & .023 & .147 & -.157 & .073 & -.095 & -.328 & .065 & $.730^{\mathrm{a}}$ & -.129 & .054 & -.312 & -.098 \\
\hline & V14 & -.289 & -.085 & .069 & -.207 & .068 & .063 & -.133 & -.129 & $.657^{a}$ & -.099 & -.004 & .110 \\
\hline & V18 & .076 & .119 & .056 & -.322 & -.295 & .242 & .033 & .054 & -.099 & $.547^{\mathrm{a}}$ & -.280 & -.271 \\
\hline & V19 & -.234 & -.040 & -.079 & .013 & .174 & .128 & -.441 & -.312 & -.004 & -.280 & $.676^{\mathrm{a}}$ & -.072 \\
\hline & V20 & -.317 & -.240 & .110 & -.121 & .334 & -.163 & -.136 & -.098 & .110 & -.271 & -.072 & $.601^{\mathrm{a}}$ \\
\hline
\end{tabular}

a. Measures of Sampling Adequacy(MSA)

Sumber: Hasil Penelitian (2017)

Tabel 5. Communalities

\begin{tabular}{lll}
\hline & Initial & Extraction \\
\hline V1 & 1.000 & .673 \\
\hline V2 & 1.000 & .683 \\
\hline V3 & 1.000 & .560 \\
\hline V5 & 1.000 & .856 \\
\hline V6 & 1.000 & .775 \\
\hline V7 & 1.000 & .727 \\
\hline V9 & 1.000 & .553 \\
\hline V13 & 1.000 & .629 \\
\hline V14 & 1.000 & .440 \\
\hline V18 & 1.000 & .708 \\
\hline V19 & 1.000 & .729 \\
\hline V20 & 1.000 & .764 \\
\hline
\end{tabular}

Extraction Method: Principal Component Analysis.

Sumber: Hasil Penelitian (2017)

Untuk tingkat signifikansi diketahui sebesar 0,000 dengan KMO and Barttlet's Test yang ditentukan dengan angka Chi Square sebesar 180,046. Barlett Test ini merupakan tes untuk menguji apakah variabel-variabel berkorelasi. Sehingga dapat dipercaya bahwa antar variabel terdapat korelasi. Dalam proses analisis faktor penelitian ini hanya dibutuhkan 1 kali proses pengolahan dikarenan semua nilai MSA item pernyataan sudah diatas 0,5 sehingga tidak ada item pernyataan yang perlu dikeluarkan dan variable penelitian dapat dilakukan proses selanjutnya, hal ini dapat dilihat pada tabel Output Analisa Faktor tabel Anti Image Matrices (AIM). 
Tabel 6.Total Variance Explained

\begin{tabular}{|c|c|c|c|c|}
\hline \multirow[t]{2}{*}{ Component } & \multicolumn{2}{|c|}{ Initial Eigenvalues } & \multicolumn{2}{|c|}{ Extraction Sums of Squared Loadings } \\
\hline & Total & $\%$ of Variance & Total & $\%$ of Variance \\
\hline 1 & 3.252 & 27.100 & 3.252 & 27.100 \\
\hline 2 & 1.561 & 13.010 & 1.561 & 13.010 \\
\hline 3 & 1.235 & 10.290 & 1.235 & 10.290 \\
\hline 4 & 1.044 & 8.699 & 1.044 & 8.699 \\
\hline 5 & 1.003 & 8.359 & 1.003 & 8.359 \\
\hline 6 & .885 & 7.372 & & \\
\hline 7 & .770 & 6.416 & & \\
\hline 8 & .676 & 5.636 & & \\
\hline 9 & .549 & 4.574 & & \\
\hline 10 & .414 & 3.447 & & \\
\hline 11 & .346 & 2.880 & & \\
\hline 12 & .266 & 2.216 & & \\
\hline
\end{tabular}

Sumber: Hasil Penelitian (2017)

Dari atribut faktor kebudayaan karena adanya muatan lokal diperoleh nilai 0,673 artinya $67,3 \%$, atribut faktor kebudayaan karena pengaruh dari lingkungan tempat tinggal diperoleh nilai 0,683 artinya $68,3 \%$, atribut faktor kebudayaan karena persamaan segi budaya dan lingkungan diperoleh nilai 0,560 artinya $56 \%$, atribut faktor kebudayaan karena dapat bermanfaat bagi pengembangan budaya dan lingkungan diperoleh nilai 0,856 artinya $85,6 \%$, atribut faktor sosial karena komunitas lingkungan sepermainan dan teman sekolah diperoleh nilai 0,775 artinya $77,5 \%$, atribut faktor sosial karena pendapat anggota keluarga diperoleh nilai 0,727 artinya $72,7 \%$, atribut faktor sosial karena status keluarga dalam masyarakat diperoleh nilai 0,553 artinya $55,3 \%$, atribut faktor pribadi karena pendapatan orang tua diperoleh nilai 0,629 artinya $62,9 \%$, atribut faktor pribadi karena melihat keberhasilan lulusannya diperoleh nilai 0,440 artinya $44 \%$, atribut faktor psikologi karena meningkatkan status sosial diperoleh nilai 0,708 artinya $70,8 \%$, atribut faktor psikologis karena mudahnya penyelesaian studi diperoleh nilai 0,729 artinya $72,9 \%$, dan atribut faktor psikologis karena tenaga pengajar (Dosen) yang berkualitas diperoleh nilai 0,764 artinya 76,4\%. Dari hasil Tabel 6, diketahui bahwa terdapat 12 variabel yang akan dimasukkan kedalam analisis faktor. Dengan masingmasing variabel mempunyai varians 1 , maka total varians adalah $12 \times 1=12$.

Berdasarkan tabel 6 diatas, menunjukan bahwa persentase dari faktor kebudayaan karena adanya muatan lokal memiliki eigenvalue sebesar 3,252 dengan nilai varian sebesar $27,1 \%$, faktor kebudayaan karena pengaruh dari lingkungan tempat tinggal memiliki eigenvalue sebesar 1,561 dengan nilai variance sebesar 13,01\%, faktor kebudayaan karena persamaan segi budaya dan lingkungan memiliki eigenvalue sebesar 1,235 dengan nilai variance sebesar 10,29\%, faktor kebudayaan karena dapat bermanfaat bagi pengembangan budaya dan lingkungan memiliki eigenvalue sebesar 1,044 dengannilai variance sebesar $8,699 \%$, faktor sosial karena komunitas lingkungan sepermainan dan teman sekolah memiliki eigenvalue sebesar 1,003 dengan nilai variance sebesar $8,359 \%$, faktor sosial karena pendapat anggota keluarga memiliki 
eigenvalue sebesar 0,885 dengan nilai variance sebesar $7,372 \%$ dan faktor sosial karena status keluarga dalam masyarakat memiliki eigenvalue sebesar 0,770 dengan nilai variancesebesar $6,416 \%$, factor pribadi karena pendapatan orang tua memiliki eigenvalue sebesar 0,676 dengan nilai variance sebesar $5,636 \%$, faktor pribadi karena melihat keberhasilan lulusannya memiliki eigenvalue sebesar 0,549 dengan nilai variance sebesar 4,574\%, faktor psikologi karena meningkatkan status sosial memiliki eigenvalue sebesar 0,414 dengan nilai variance sebesar $3,447 \%$, faktor psikologis karena mudahnya penyelesaian studi memiliki eigenvalue sebesar 0,346 dengan nilai variance sebesar $2,88 \%$, dan faktor psikologis karena tenaga pengajar (Dosen) yang berkualitas memiliki eigenvalue sebesar 0,266 dengan nilai variance sebesar $2,216 \%$. Jadi, kedua belas faktor-faktor tersebut mempengaruhi mahasiswa baru dalam memilih program studi pada Fakultas Ekonomi Universitas Samudra.

\section{KESIMPULAN}

Berdasarkan hasil analisis data dan pembahasan, maka dapat disimpulkan yaitu faktor-faktor yang mempengaruhi mahasiswa baru memilih program studi pada Fakultas Ekonomi Universitas Samudra dengan faktor dominan adalah faktor budaya karena adanya muatan lokal, pengaruh lingkungan tempat tinggal, persamaan segi budaya dan lingkungan, pengembangan budaya dan lingkungan dan faktor sosial karena komunitas lingkungan sepermanian dan teman sekolah yang memiliki eigenvalue $>1$.

\section{DAFTAR PUSTAKA}

\section{Fadjar, Malik A. 2005. Holistika Pemikiran}

Pendidikan. Jakarta: PT. Raja, Grafindo Persada. Gramedia Liberty.

Kartono, Kartini dan Gulo, Dali. 1987. Kamus Psikologi. Bandung: Pionir Jaya Kelompok Gramedia

Kotler, Philip and Amstrong, Gary. 2012, Principles of Marketing, Fourteen Edition, England: Pearson Education Limited.
2004.

Dasar-dasar Pemasaran. Jakarta: PT.Indeks

dan Susanto. 2001.

Manajemen Perusahaan. Jakarta:

Salemba Empat

Parasuraman, A., Zeithalm, V.. dan Berry L.. 2005. SERVQUAL: A Multiple item. PT. Logos Wacana Ilmu.

Robbins, Stephen. 2003. Perilaku Organisasi. jilid satu. Jakarta: PT Indeks

Schiffman, Leslie. 2004. Perilaku Konsumen. Edisi ke tujuh. Jakarta: Indeks.

Simamora, Bilson. 2004. Panduan Riset Prilaku Konsumen. Jakarta: PT.Gramedia

2007. Panduan Riset Perilaku Konsumen. Jakarta: PT Gramedia Pustaka Utama.

Sugiyono. 2007. Metode Penelitian Administrasi. Bandung: Alfabeta

Umar,Husein. 2003. Riset pemasaran dan Perilaku Konsumen. Yogyakarta: PT. Pustaka Utama. 